http://dx.doi.org/10.15762/ZH.2017.59

\title{
The Image of Towns in the Pre-partition Polish Lands TORUŃ, JUNE 8-9, 2018
}

One of the aftermaths of the cultural turn in the humanities was that the way of thinking about the world and perception of reality attracted the attention of historical scientists. New methodological challenges brought about an increased interest in the issue of the image of the town and perception of towns and townspeople by historians, art historians and literary historians, marked since the 1980s. However, it is noteworthy that the tradition of research on the representation of towns, whether created by means of iconography or words, is earlier than the influence of postmodernism. Already in 1925 Robert Ezra Park, a pioneer of the urban sociology, paid attention to the significance of the town as a mental phenomenon, resulting from processes of perception ${ }^{1}$. The research on the literary and artistic forms of creating the town image developed many years later, from the mid- $20^{\text {th }}$ century. Simultaneously, in his book The Image of the City published in 1960, an American urbanist, Kevin Lynch, presented the results of the research on individual processes of perceiving the town and shaping its mental images ${ }^{2}$. In the early 1970s Aron Gurevich considered the image of the world and medieval mode of perceiving the world as universal categories, critical to the understanding of the European Middle Ages $^{3}$. The works of geographers and a French philosopher, Henri Lefèbvre, published in the 1970s, inspired further studies of the perception of the urban space and the creation of its image ${ }^{4}$. At the time, under the influence of the Annales school, the issue of the image of towns aroused interest of scholars

${ }^{1}$ Robert E. PArk, Ernest W. Burgess, Roderick D. McKenzie, The City. Suggestions for the Study of Human Nature in the Urban Environment, Chicago 1925.

${ }^{2}$ John K. Hyde, Medieval Descriptions of cities, Bulletin of the John Rylands Library, vol. 48: 1965-1966, pp. 308-340; Pierre Lavedan, Représentations des villes dans l'art du Moyen Âge, Paris 1954; Kevin Lynch, The Image of the City, Cambridge 1960.

${ }^{3}$ Aron Guriewicz, Kategorie kultury średniowiecznej, trans. Józef Dancygier, Warszawa 1976, p. 17.

${ }^{4}$ Henri Lefèbvre, La production de l'espace, Paris 1974; Yi-Fu Tuan, Images and Mental Maps, Annals of the Association of American Geographers, vol. 65: 1975, no. 2, pp. 205-214; Antoine BAILly, La perception de l'espace urbain: les concepts, les méthodes, leur utilisation dans la recherche urbanistique, Paris 1977. 
studying the culture and burgher's mentality. Near the end of the 1970s, the symptoms of the methodological breakthrough emerged. Its essential feature was the departure from universal images of the world in favour of the individual perception; moreover, the processes of perceiving and creating images started to be considered in the broad context of social and political conditions. In the histoire de l'imaginaire Jacques Le Goff advanced the study of the use of images in the act of creation of individual and collective identities ${ }^{5}$. Furthermore, Otto Gerhard Oexle presented an inspirational study on the interpretation schemes employed in the processes of perception in the Middle Ages, which indicated new possibilities of research on reading and understanding the meanings implicit in the images ${ }^{6}$. The methodological trend of imagined history (Vorstellungsgeschichte) developed since the 1980s, has contributed to the increase of the interest in issues of the urban image as well'. This approach is still present in the European historiography ${ }^{8}$.

In the Polish research on the history of towns in the pre-industrial era, the problem of perception and representation of towns started to be discussed in the 1990s. It is beyond the scope of this introduction to comprehensively present the result of the studies; however, even a cursory review of the publication clearly points to the variety of thematic approaches to the problem of the town image. What has met with particular interest of researchers was the image of towns and townspeople presented in literary and historiographical works and travel descriptions?. This problem has been usually undertaken on

${ }^{5}$ Jacques Le Goff, L'imaginaire medieval, Paris 1985.

${ }^{6}$ Otto Gerhard OexLe, Die funktionale Dreiteilung der Geschichte 'Gesellschaft' bei Adalbero von Laon. Deutungsschemata der sozialen Wirklichkeit im früheren Mittelalter, Frühmittelalterliche Studien, vol. 12: 1987, pp. 1-54.

${ }^{7}$ Hans-Werner Goetz, 'Vorstellungsgeschichte'. Menschliche Vorstellungen und Meinungen als Dimension der Vergangenheit. Bemerkungen zu einem jüngeren Arbeitsfeld der Geschichtswissenschaft als Beitrag zu einer Methodik der Quellenauswertung, Archiv für Kulturgeschichte, Bd. 61: 1979 (printed 1982), pp. 253-271.

${ }^{8}$ See e.g. Towns and Cities of the Croatian Middle Ages. Image of the Town in the Narrative Sources: Reality and/or Fiction?, ed. Irena Benyovsky Latin, Zrinka Pešorda Vardič, Zagreb 2017.

${ }^{9}$ The precursory studies were undertaken by Maria Bogucka, Das Bild der Stadt im Poem 'Flösserei' von Sebastian Fabian Klonowic, [in:] Literatur und Institutionen der literarischen Kommunikation in nordeuropäischen Städten im Zeitraum vom 16. bis zum 18. Jahrhundert, hrsg. v. Edmund Kotarski, Gdańsk 1996, pp. 38-46; eadem, Die Weichselstädte im Bild der polnischen Literatur des ausgehenden 16. und der ersten Hälfte des 17. Jahrhunderts, [in:] Bild und Wahrnehmung der Stadt, hrsg. v. Peter Johanek, Köln-Wien-Weimar 2012, pp. 71-78; Andrzej Wyrobisz, Mieszczanie w opinii staropolskich literatów, Przegląd Historyczny, vol. 82: 1991, no. 1, pp. 51-77. 
the basis of written and iconographic sources concerning the largest cities ${ }^{10}$. The studies of religiosity and sacral topography of towns have referred to the issues of the perception of towns and creation of their image. The latter has also been an important element in the studies of the urban order in the Polish territories ${ }^{11}$. Of key significance for the topic of our interest is the research on the urban sigillography, developing in the last decade ${ }^{12}$.

However, appreciating the achievements, one should also bear in mind the research deficits; among them, particularly severe are the lack of typological approach to the phenomenon under study as well as the scarcity of theoretical reflection and interdisciplinary discussion. Such a situation lay at the root of the decision of the Commission for Urban History of the Polish National Historical Committee of the Polish Academy of Sciences to respond to the need of organizing a conference on the image of the town in the Polish lands in the pre-industrial era. The conference that took place in Torun was co-organized by the Institute of History and Archival Sciences of the Nicolaus Copernicus University on June 8-9, 2018. The organizers' intention was to invite an interdisciplinary group of speakers, including historians, urbanists, art historians and philologists. The notion of 'image' included in the conference title is understood as a historically conditioned construction, a result of the conscious, or based on knowledge and experience, perception of reality, both past and present. The papers referred to the images interpreted as the urban and spatial form of the town, town's residents, and the political aspects of urban life. The conference participants employed various types of primary sources containing

\footnotetext{
${ }^{10}$ Jadwiga Krzyżaniakowa, Gdańsk w średniowiecznej historiografii polskiej, [in:] Gdańsk średniowieczny w świetle najnowszych badań archeologicznych i historycznych, ed. Henryk PANER, Gdańsk 1998, pp. 142-146; Dariusz KaCzor, 'Orbis Gedanense'. Wizja Gdańska w kronice dominikanina Martina Grunewega (XVI w.), [in:] Dominikanie. Gdańsk - Polska - Europa. Materialy $z$ konferencji międzynarodowej pt. 'Gdańskie i europejskie dziedzictwo. Zakon dominikanów w dziejach Gdańska', ed. Dariusz Aleksander DeKański et al., Gdańsk-Pelplin 2003, pp. 549-569; Klasztory, miasta i zamki w życiu i twórczości Jana Długosza, ed. Jerzy Rajman, Dorota ŻureK, Kraków 2016; Miasto w obrazie, legendzie, opowieści, ed. Róża Godula-WęCŁAwowicz, Kraków-Wrocław 2008.

${ }^{11}$ See for instance Roman Micha£owski, Princeps fundator. Studium z kultury politycznej w Polsce X-XIII wieku, Warszawa 1989; Halina ManiкowsкA, Geografia sakralna miasta, [in:] Animarum cultura. Studia nad kultura religijnq na ziemiach polskich w średniowieczu, ed. Halina MANiKowsKa, Wojciech Brojer, Warszawa 2008, pp. 95-132.

${ }^{12}$ Marek Adamczewski, Heraldyka miast wielkopolskich do końca XVIII wieku, Warszawa 2000; Henryk SerokA, Herby miast małopolskich do końca XVIII wieku, Warszawa 2002; Beata Mоż̇јко, Przywileje Kazimierza Jagiellończyka z 1457 r. dla Gdańska a zmiany heraldycznego wizerunku miasta, [in:] Okręt Kościoła z gdańskiego Dworu Artusa, ed. Edward ŚLEDź, Gdańsk 2008, pp. 5-37.
} 
the images of towns, such as written sources (chronicles, panegyric literature, hodoeporicons) as well as iconographic materials (seals, views, cityscapes) and cartographic sources. It is worth mentioning that the conference of the Commission for Urban History was accompanied by the conference of young researchers of the history of towns, devoted to the issue of town and nature.

Prof. dr hab. Roman Czaja Institute of History and Archival Studies Nicolaus Copernicus University in Toruń

Prof. dr hab. Zdzisław Noga Institute of History and Archival Sciences Pedagogical University of Cracow trans. by Anna Maleszka

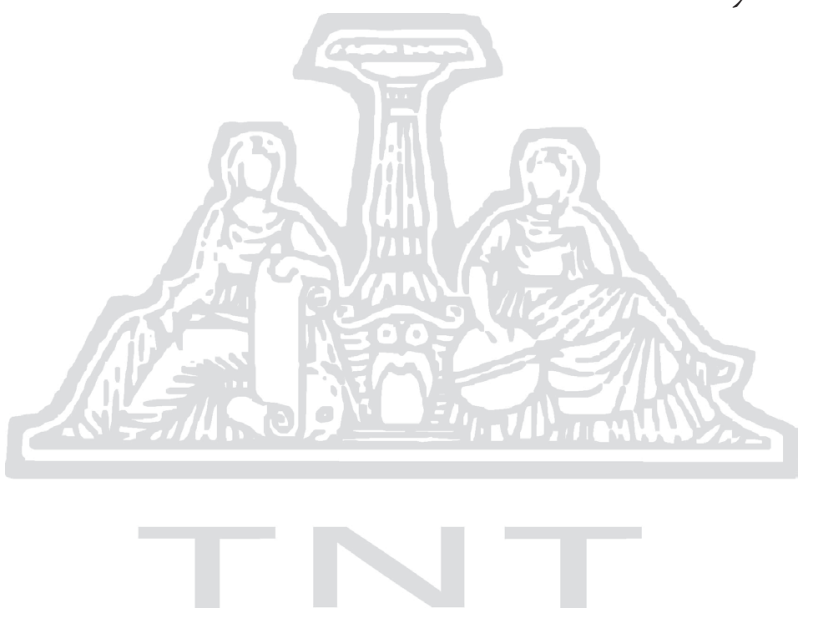

